\title{
W STULECIE ZAKłADU HELCLÓW W KRAKOWIE $(1890-1990)$
}

Dnia 4 września 1990 roku odbyła się w Krakowie podniosła uroczystość. Państwowy Dom Pomocy Społecznej im. Helclów obchodził 100-lecie istnienia. Jubileuszowe obchody rozpoczęły się w kaplicy domu mszą św., którą celebrował Jego Eminencja Franciszek kardynał Macharski. W uroczystościach wzięli także udział między innymi wiceminister zdrowia i opieki społecznej Krystyna Sienkiewicz, wojewoda krakowski Tadeusz Piekarz, prezydent m. Krakowa Jacek Woźniakowski, ks. bp Albin Małysiak, który w latach 40-tych był kapelanem tego zakładu. Dziś, tak jak przed stu laty, Dom im. Helclów dalej służy ludziom potrzebującym szczególnej opieki. Ponieważ działalność filantropijna należy do pięknych kart historii Polski 2. połowy XIX wieku, a także naszego stulecia, warto zasygnalizować tę tak aktualną niegdyś sprawę także i dziś.

Dziewiętnastowieczny Kraków był miejscem, gdzie z prywatnych fundacji powstał szereg zakładów dobroczynnych. Część społeczeństwa żyjąca w biedzie, nawet w nędzy, stale powiększała swą liczebność. Dotychczasowe formy działalności filantropijnej (bale karnawałowe, festyny, wenty, loterie „dla ubogich") pozostawały mało skuteczne. Odzewem na tego rodzaju potrzeby społeczne była działalność stowarzyszeń filantropijnych, zarówno chrześcijańskich, jak i żydowskich. Najpoważniejsze zasługi na rzecz pomocy najbiedniejszym miało Krakowskie Towarzystwo Dobroczynności, zatwierdzone przez władze miasta 30 października 1816 roku. W listopadzie tegoż roku Towarzystwo wystosowało apel do ludności Krakowa, zwracając się o dary na rzecz mającego powstać Domu Schronienia Ogólnego dla starców, sierot i kalek. Początkowo działalność Towarzystwa sprowadzała się do opieki nad osobami dorosłymi. Dochody pochodziły z dobrowolnych ofiar, składek członkowskich, dopłat do biletów teatralnych, z kwest, fundacji możnych itp. W lutym 1817 roku, zyskując stałą siedzibę, podopieczni Towarzystwa wprowadzili się do jednego ze skrzydeł Zamku na Wawelu. Dysponowano 26 salami, przy czym każda z sal miała przydzielonego opiekuna. Ponieważ opieką zostały objęte także dzieci, od 1818 roku zaangażowano dla nich stałego nauczyciela. 
W dziesięć lat później zakład liczył 350 pensjonariuszy. Wzrost liczby osieroconych dzieci (epidemia cholery w Krakowie) spowodował przeznaczenie dolnych kondygnacji zamku wawelskiego na szkołę, zyskano także osobne pomieszczenia dla dziewcząt i chłopców. W 1844 roku powstał dodatkowy wydział ochron dla małych dzieci. Po upadku powstania krakowskiego wojska austriackie zajęły pomieszczenia na Wawelu i Dom Schronienia Ogólnego został zlikwidowany. Podopieczni Towarzystwa znaleźli schronienie w klasztorach Dominikanów, Franciszkanów, Pijarów, Paulinów na Skałce, Kanoników lateraneńskich u Bożego Ciała. Dzieci umieszczono w klasztorze przy kościele św. Tomasza. Ówczesne kłopoty finansowe Towarzystwa pogłębiły zarówno powstanie chłopskie w Galicji w 1846 roku, jak też pożar, który pochłonął składy zapasów. Sytuacja poprawiła się w 1854 roku, kiedy to nastąpiło przeniesienie części zakładu do gmachu przyklasztornego na Stradomiu na mocy zapisu testamentowego na rzecz Towarzystwa. Dopiero zakup przyległej realności (1860) pozwolił na przeniesienie wszystkich pensjonariuszy do nowego obiektu. W 1873 roku Komisja Szkolna Towarzystwa zorganizowała szkołę dla sierot z zamiarem uczynienia z niej placówki wzorowej. Tam też od 1883 roku rozpoczęto naukę rzemiosła dla chłopców, a w 1883 wprowadzono naukę gimnastyki, która odbywała się w budynkach Towarzystwa „Sokół”. Wybuch I wojny światowej zakończył działalność Krakowskiego Towarzystwa Dobroczynności, a budynki będące jego własnością zostały zajęte na szpitale wojskowe.

Wybitne zasługi na rzecz pomocy najbiedniejszym miała w tym czasie działalność Adama Chmielowskiego, malarza i powstańca 1863 roku, znanego jako Brat Albert. Przybył do Krakowa w 1884 roku, zatrzymał się w zakonie kapucynów i tam rozpoczął pracę $\mathrm{z}$ bezdomnymi. W miastach istniały wtedy tzw. ogrzewalnie, służące za schronienie najuboższym, jednak miejsca te pozostawione bez dozoru i opieki stawały się źródłem chorób i demoralizacji. Brat Albert przejął ogrzewalnię krakowską, odnowił ją i uporządkowal, a także kwestował na rzecz ubogich, tworzył warsztaty pracy, aby zdolni do pracy mogli zarabiać na swoje utrzymanie. W 1888 roku złożył śluby zakonne, uważane za akt założenia Zgromadzenia Braci Albertynów. Regułą tego Zgromadzenia był nakaz całkowitego ubóstwa, dlatego żadnego z przytułków ani gospodarstw nie posiadali na własność, pozostając tylko ich użytkownikami. W dowód uznania ich pełnej poświęcenia pracy Rada Miejska zakupiła w 1892 roku realność przy ulicy Krakowskiej i Skawińskiej na schronisko dla biednych. Z inicjatywy Brata Alberta powstały przytułki także w innych miastach: we Lwowie, Sokalu, Tarnowie, Stanisławowie, Przemyślu i Kielcach. O roli, jaką miały one spełniać, pisze o. Bernard z zakonu Karmelitów Bosych, iż „zadaniem atoli każdego przytuliska jest dawać biedakom bodaj to, co konieczne, a więc bezdomnemu - przytułek, głodnemu — pożywienie, bez odzieży czy bosemu — choćby ciepły kącik i w ogóle jakiś poratunek tym, którzy się znaj- 
dują w skrajnej nędzy lub potrzebie" ${ }^{1}$. Brat Albert zmarł w 1916 roku. Otoczony podziwem i szacunkiem przez jednych (hr. Zamojski, hr. Tarnowscy, hr. Hubert Rostworowski) spotykał się też z niezrozumieniem i niechęcią. W uznaniu jego pełnej poświęcenia pracy wolna Rzeczpospolita przyznała mu Wielką Wstęgę Orderu Odrodzenia Polski „za wybitne zasługi w działalności niepodległościowej i na polu pracy społecznej"2.

W tym czasie w Krakowie powstało szereg nowych szpitali i zakładów dobroczynnych. Z funduszy prywatnych wybudowano w latach $1874-1876$ szpital dziecięcy im. Sw. Łazarza, w 1890 oddano do użytku Dom Ubogich im. Helclów, schronisko im księcia A. Lubomirskiego, a także bursę dla młodzieży rzemieślniczej, założoną przez ks. Mieczysława Kuznowicza w 1914 roku.

Na szczególną uwagę zasługują dwa z powyższych założeń: dom im. Helclów i zakład dla chłopców fundacji Aleksandra Lubomirskiego. Fundacja Lubomirskiego w początkowym projekcie obejmować miała zakład dla opuszczonych chłopców, a także zakład dla dziewcząt, na który przeznaczył osobną sumę. Z powodu ograniczonej powierzchni gruntu przeznaczonego pod budowę, zakład dla dziewcząt powstał w Łagiewnikach w roku 1890. Realizację drugiej z zamierzonych fundacji ukończono $\mathrm{w}$ roku 1893. Zanim to jednak nastąpiło, rozpisano konkurs architektoniczny, ponieważ Lubomirski, jako fundator obiektu, przywiązywał dużą wagę zarówno do jego funkcjonalności, jak i okazałości, czyniąc szczegółowe zastrzeżenia w akcie fundacyjnym. Do realizacji przyjęto projekt Tadeusza Stryjeńskiego i Władysława Ekielskiego jako ten, którzy najpełniej odpowiadał wymaganiom fundatora. Główny gmach ma kompozycję symetryczną i pozostaje w typie założenia pałacowego „entre cour et jardin". Fasada charakteryzuje się trzema mało wystającymi ryzalitami, odpowiadającymi trzem skrzydłom korpusu. Ryzalit główny zwieńczony jest ośmioboczną kopułą. Istotny element dekoracyjny stanowi zarówno sgraffitowa dekoracja na elewacji budynku, jak i renesansowe okna. Oprócz budynku głównego postawiono w ogrodzie pawilony, które służyć miały za miejsce do przyuczania w różnych zawodach. Schronisko wyposażone było także w salę gimnastyczną i basen kąpielowy. W 1914 roku schronisko przekształcono w szpital dla zakaźnie chorych. W cztery lata później budynki zakładu zostały przeznaczone na szpital wojskowy, później na cele administracyjne. Ponowne otwarcie schroniska o pierwotnym przeznaczeniu nastąpiło w 1925 roku. Z wybuchem II wojny światowej władze niemieckie przeznaczyły obiekt na cele wojskowe. Później budynek ten służył kolejno za obóz repatriacyjny dla żołnierzy państw zachodnich, za szpital wojskowy Armii Czerwonej, aby od roku 1946 ponownie spełniać rolę schroniska. W 1950 roku budynek przeznaczono na

${ }^{1}$ O. B ern ard (karmelita bosy), Duchowość Brata Alberta, Kraków 1938, s. 210.

${ }^{2}$ W. Smole ń, Od piękna sztuki do piękna mitości, [w:] Brat Albert. Życie i dzieto, red. J. Majdecki, Warszawa 1978, s. 12. 
dom akademicki dla studentów Akademii Medycznej. Ostateczny kres istnienia fundacji miał miejsce w 1952 roku, kiedy budynki przy ulicy Rakowickiej przekazano w użytkowanie Akademii Ekonomicznej.

Także w tym czasie powstał w Krakowie wspomniany na wstępie zakład o charakterze dobroczynnym, przeznaczony dla ubogich, z fundacji Ludwika i Anny Helclów. Został zbudowany w latach 1886 - 1890 według projektu Tomasza Przylińskiego kosztem ponad $560000 \mathrm{złr}$. Uczestnikami uroczystego oddania wraz z konsekracją budynku i kaplicy byli między innymi: hr. Stanisław Tarnowski jako przedstawiciel Wydziału Krajowego (władza nadzorcza nad fundacjami), Jan Matejko, Juliusz Kossak, Władysław Łuszczkiewicz. Był to na ówczesne czasy jeden z najnowocześniejszych zakładów w Europie. Usytuowany został centralnie na dużej przestrzeni ogrodu, zachowując kształt podkowy z korpusem głównym i dwoma prostopadle przylegającymi skrzydłami z dziedzińcem pośrodku. Od strony dziedzińca wybudowano trójnawową kaplicę, podobnie jak cały gmach, o charakterze neorenesansowym. Cała posesja otoczona była murem z cegły. W zapisie testamentowym na rzecz zakładu przeznaczono także meble i obrazy sprzedane później na potrzeby jego utrzymania. Budynek został wyposażony w urządzenia gospodarcze i sanitarne na każdym piętrze, własny system wodociągowy, telefon wewnętrzny i inne udogodnienia. W suterenach znajdowały się składy żywnościowe, piekarnia, warsztaty i kotłownia. W czasie I wojny światowej i później, aż do roku 1921 zakład został częściowo zamieniony na szpital wojskowy. W latach $1921-1925$ niektóre pomieszczenia zarekwirowano dla Izby Skarbowej, a część z nich odnajmowana była przez szpital św. Łazarza. W roku 1944 zakład przeniesiono do Szczawnicy a budynki fundacji przeznaczone zostały na szpital wojskowy i koszary. Powrót pensjonariuszy do dawnej siedziby naștąpił w roku 1946. W roku 1951 zakład upaństwowiono i zmieniono nazwę na Państwowy Dom Opieki Społecznej im Helclów.

Filantropia w XIX wieku w Krakowie miała różnorodne formy ${ }^{3}$. Wymienione rodzaje działalności na rzecz ubogich pozostawiły po sobie trwały ślad. Budynki powstałe $\mathrm{z}$ hojności ówczesnych fundatorów, choć częstokroć inne jest ich przeznaczenie, służą miastu do dziś. W dawnym schronisku dla chłopców przy ulicy Rakowickiej ma obecnie swoją siedzibę Akademia Ekonomiczna, na Stradomiu mieści się obecnie dom dla nieuleczalnie chorych psychicz-

${ }^{3}$ Wspomnianą problematykę szczególowiej omawiają następujące publikacje: J. Bie niarzów na, J. M. Małe cki, J. Mit kow ski, Dzieje Krakowa, t. 3, Kraków 1979; J. B ą k, Opieka spoteczna nad sierotami w Krakowskim Towarzystwie Dobroczynności 1816 - 1916, „Rocznik Krakowski" $46: 1975 ;$ M. Chlanda-Reinchardt, Dom ubogich im. Helclów (maszynopis w Instytucie PAN w Warszawie); T. D obrowolsk i, Sztuka Krakowa, Kraków 1978; M. Ga jd a, Akt fundacyjny Domu Ubogich fundacji Ludwika i Anny Helclów, „Rocznik Krakowski” 52: 1986; K. M. Gó rs k i, Architektura XIX wieku, tamże 6: 1904; J. P u r chl a, Jak powstat nowoczesny Kraków, Kraków 1979 (Biblioteka krakowska nr 120); tenże, Schronisko fundacji księcia Aleksandra Lubomirskiego przy ulicy Rakowickiej w Krakowie, „Folia Historiae Artium” 19: 1978 s. $135-152$. 
nie, jak dawniej prowadzony przez Braci Albertynów. Towarzystwo Dobroczynności pozostawiło dom przy ulicy Koletek, a Zakład Helclów funkcjonuje do dziś nie zmieniwszy swego charakteru.

\title{
THE CENTENARY OF THE HELCELS' INSTITUTION IN CRACOW (1890 - 1990)
}

\begin{abstract}
S u m mary
On the 4 th of September 1990 was celebrated a centenary of opening „The Helcels' National House of Social Welfare”. It is one of many philantropic institutions established in this city in XIX century. The Cracow Charity Society rendered the most significant services to a poor people from 1816 to 1914, taking care about adults and children. A number of asylums for poors were founded in Cracow and other cities from inspiration of Adam Chmielowski (Brother Albert), founder of The Congregation of Albertin Brothers. In 1893 was finished the construstion of institution for orphan boys founded by duke Aleksander Lubomirski. Now this building is the seat of the Academy of Economy. The House of Poors founded by Anna and Ludwik Helcel, as one of most modern institutions of this kind in contemporary Europe, after many reconstructions and repairs, still functional and well equiped has not changed his purpose until today.
\end{abstract}





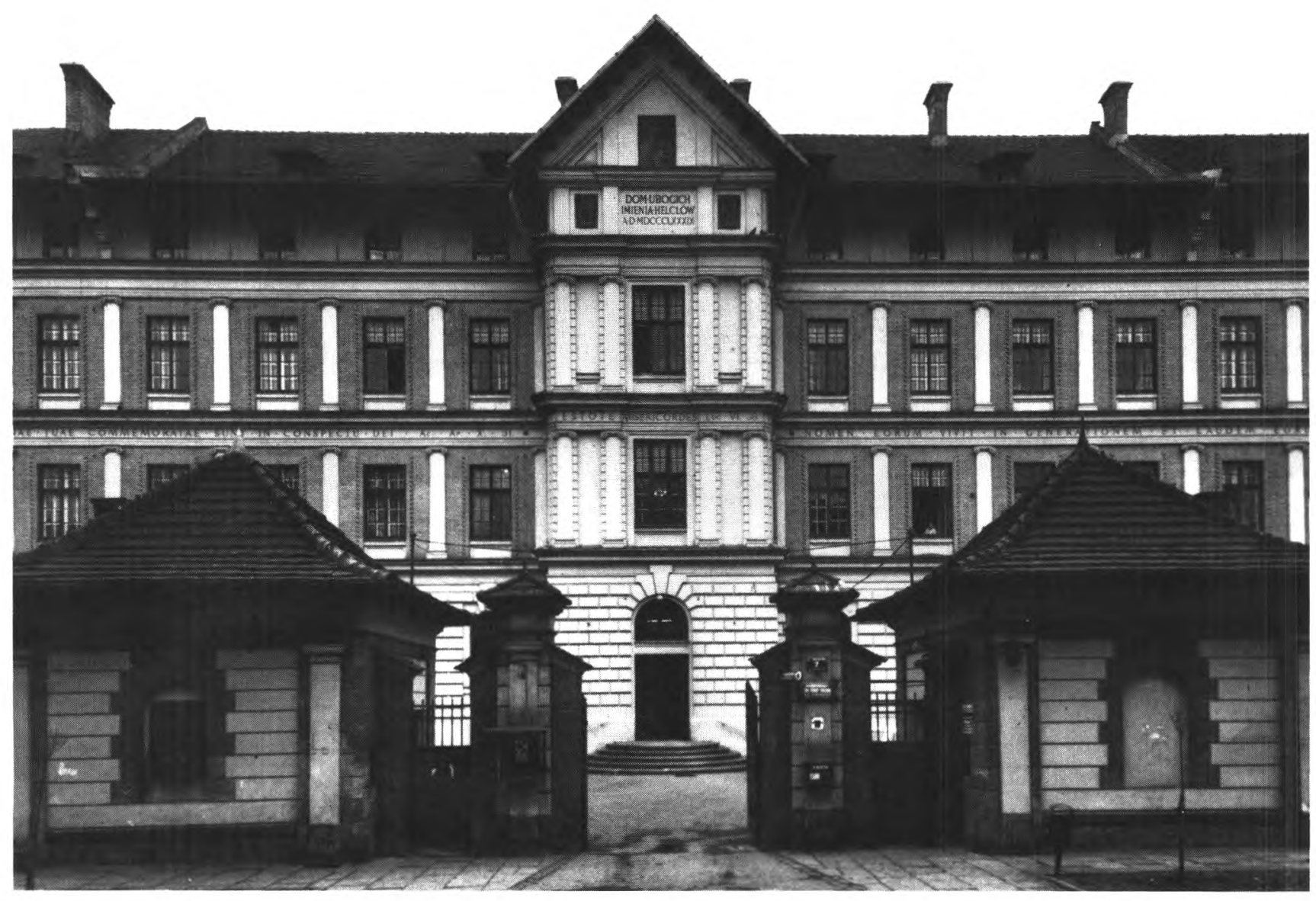

1. Fasada Zakładu im. Helclów w Krakowie. Gmach projektowany przez architekta Tadeusza Prylińskiego. Fot. J. Langda. 


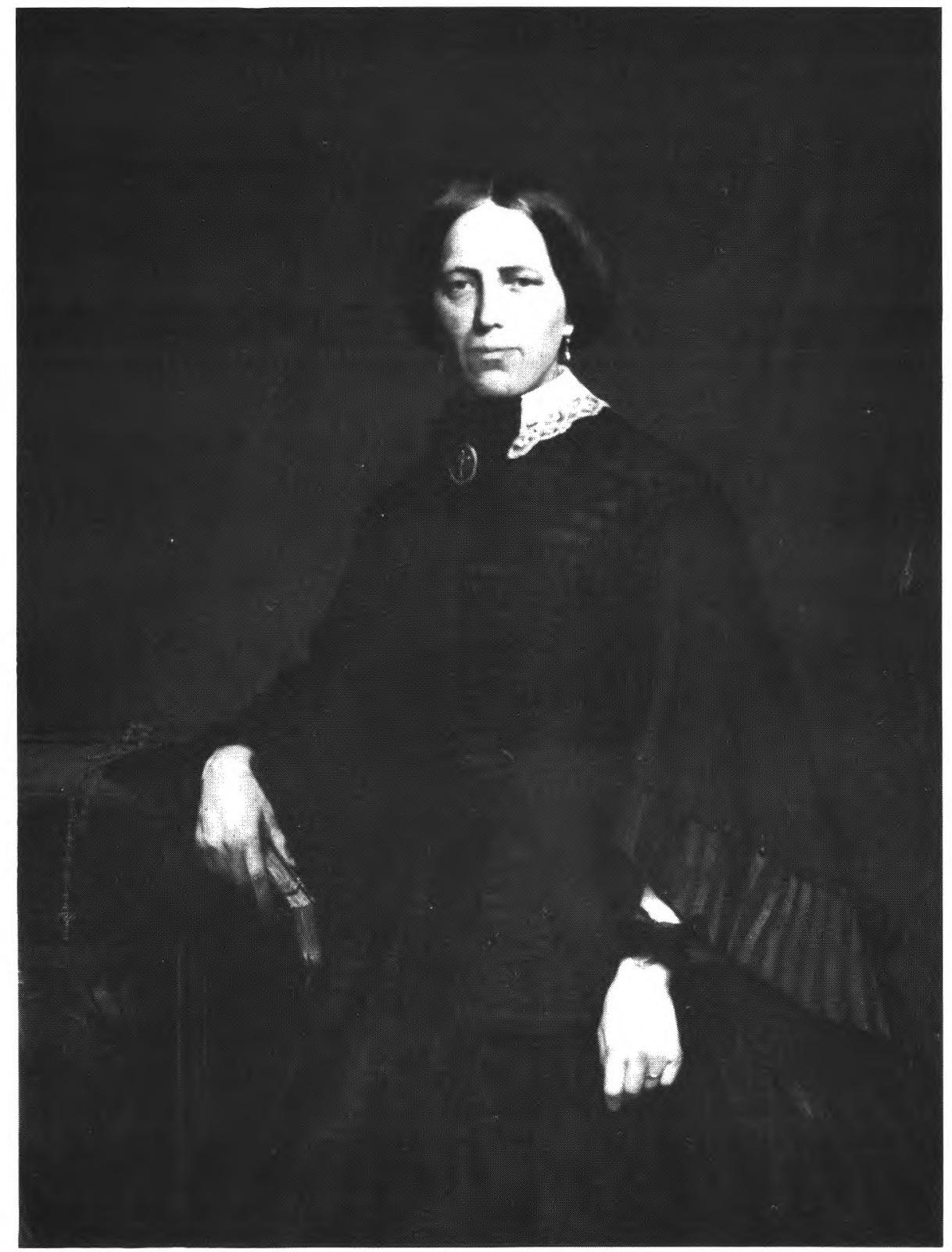

2. Anna z Treutlerów Helclowa. Portret prawdopodobnie pędzla Władysława Pochwalskiego. Zakład im. Helclów w Krakowie. Fot. J. Langda. 


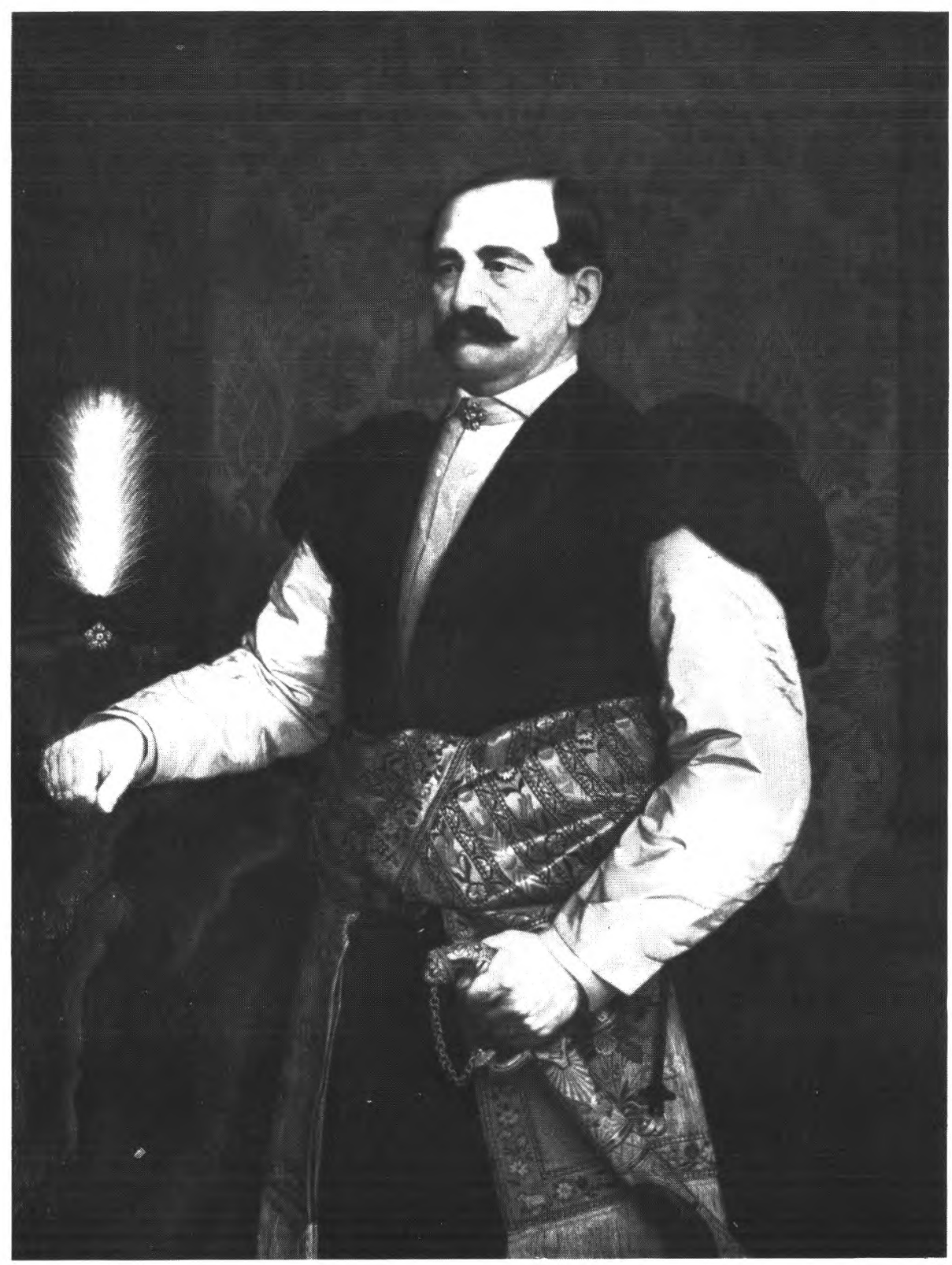

3. Ludwik Helcel. Portret prawdopodobnie pędzla W. Pochwalskiego. Zakład im. Helclów w Krakowie. Fot. J. Langda. 


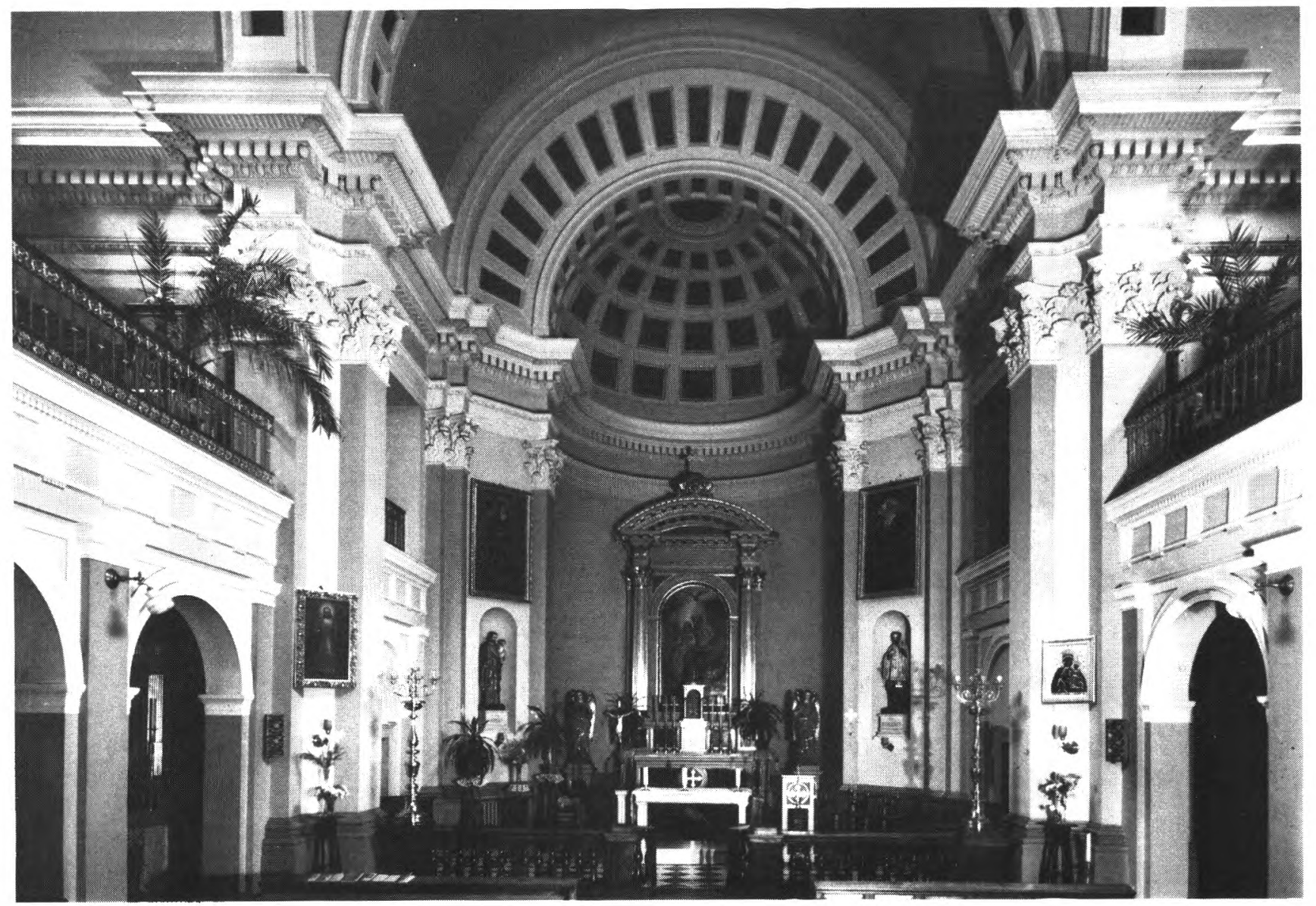

4. Wnętrze kaplicy w Zakładzie im. Helclów w Krakowie. Fot. J. Langda. 